九州大学学術情報リポジトリ

Kyushu University Institutional Repository

\title{
Cytological Study in Root Tip Cells in Four Cultivars of Sorghum bicolor
}

Duy Can, Nguyen

Laboratory of Crop Science, Faculty of Agriculture, Kyushu University

Yoshida, Tomohiko

Laboratory of Crop Science, Faculty of Agriculture, Kyushu University

https://doi.org/10.5109/24184

出版情報: 九州大学大学院農学研究院紀要. 42 (1/2)，pp.11-16，1997-12. Kyushu University バージョン：

権利関係 : 


\title{
Cytological Study in Root Tip Cells in Four Cultivars of Sorghum bicolor
}

\author{
Nguyen Duy Can and Tomohiko Yoshida \\ Laboratory of Crop Science, Faculty of Agriculture, \\ Kyushu University, Fukuoka 812-81, Japan \\ (Received July 14, 1997 and accepted August 25, 1997)
}

\begin{abstract}
Several enzyme treatments for cytological observations were tested in order to characterize chromosome configurations in sorghum root tip cells. Treatments with enzyme containing $4 \%$ cellulase and $2 \%$ pectolyase $\mathrm{Y}-23$ at $37^{\circ} \mathrm{C}$ for one or two hours provided high quality for slide preparations with darkly and clearly stained chromosomes, and made possible for counting and photomicrograph. Chromosome number of $2 n=20$ was predominant in the majority of mitotic cells of root tips in all four cultivars. A few tetraploid cells and haploid cells were also observed in this study. The variations in chromosome size was detected in four cultivars studied. The length of chromosomes ranged from 2.5 to $5.5 \mu \mathrm{m}$. The length of small chromosomes varied from 1.25 to $2.0 \mu \mathrm{m}$. These observations confirmed earlier findings that the variations of chromosome morphology in several sorghum species existed.
\end{abstract}

\section{INTRODUCTION}

Sorghum bicolor is considered as a diploid species with characteristic chromosome number of $2 n=20$ (Gu et al., 1984; Sangduen et al., 1984; Wu, 1993). Some studies on morphological characteristics and chromosome behavior in some certain species of sorghum were reported. Pairs of homologues from the morphology of the chromosomes and differences in size were identified in $S$. bicolor (Gu et al., 1984). From the morphology of the chromosome, phenomena of somatic chromosomes associated into several groups and end-to-end chromosome association in $S$. bicolor were confirmed (Tang et al., 1987). These facts indicate broad morphological variability, even within a species, and wide adaptation to various habitats of sorghums. Due to the diversity and variability of sorghums, more specific studies, especially on chromosome characteristic that defined their heredity are required.

Regarding to technique for cytological observations, Tang et al. (1987) stated that staining and spreading of chromosomes in sorghum root tip cells were difficult processes. As results from his study, an improved technique for cytological observations in sorghum root tips was reported involving effects of pectinase concentration in enzyme treatment. However, in practice there are always difficulties in getting good slide preparations because of many problems. Technique for chromosome observations described by Hyuga (1990) could be adaptable to sorghum plants and overcome some disadvantages of previous studies if some modifications were offered.

Our objectives in this study were to search for a better method for observation of chromosomes in sorghum root tips and to attempt to characterize some characteristics of chromosome in four cultivars of $S$. bicolor. 


\section{MATERIALS AND METHODS}

Four cultivars consisted of TX403, PP290, Xin White (from USA) and C8 (from Chugoku National Agr. Exp. Stn.) were used for this study. Technique for chromosome observations was based on the procedures described by Hyuga (1990) with some modifications. Seeds were germinated on moistened filter paper in a Petri dish at $25^{\circ} \mathrm{C}$. Root tips were collected when they were $1 \mathrm{~cm}$ in length. Excised root tips (about $1 \mathrm{~mm}$ long) were pretreated in $0.1 \%$ colchicine solution for 1 hours in darkness at room temperature $\left(24-25^{\circ} \mathrm{C}\right)$. After pretreating, root tips were fixed in a fixative [3:1 $99.7 \%$ ethanol: acid acetic $(\mathrm{v} / \mathrm{v})]$ at $4-5^{\circ} \mathrm{C}$ for 1 hour. After root tips were removed from the fixative, they were immersed in an ethanol series $(50 \%, 25 \%, 12.5 \%, 6,3 \%$ by vol.) and distilled water for 5 minutes intervals. In this study, series of enzyme mixture were used for testing. Treatments of enzyme mixture consisted of: (1) $4 \%$ cellulase and 1\% pectolyase Y-23, (2) 4\% cellulase and 2\% pectolyase Y-23, and (3) 5\% cellulase and 3\% pectolyase Y-23. These were added with $75 \mathrm{mM} \mathrm{KCl}, 7.5 \mathrm{mM} \mathrm{Na}{ }_{2}$ EDTA and adjusted to $\mathrm{pH}$ 4.0. A root tip was placed on a clean slide glass, added with a drop of an enzyme mixture, followed by incubation at $37^{\circ} \mathrm{C}$. Treatments of duration for 30 minutes, 1 hour and 2 hours were applied for all three kinds of enzyme. Slides with treated roots were rinsed well with distilled water to remove enzyme. After removing excess water, treated root tip was again added with a few drops of fixative and smashed thoroughly with a needle. Root tip cells on a slide glass were stained in $5 \%$ Giemsa's solution diluted with $1 / 15 \mathrm{M}$ phosphate buffer solution at room temperature for 1 hour. Quality of the slides were scored visually according to the result. High scoring was given for stained chromosomes which were clearly visible and could be easily counted.

For cytological studies, chromosomes were observed, counted and photographed using a Nikon microflex AFX-DX attachment on a Nikon light microscope.

In another experiment, root tips from the same four cultivars were collected and pretreated with $0.05 \%$ colchicine for 2 hour. These roots were then fixed in a fixative at $4-5^{\circ} \mathrm{C}$ with four treatments of duration for 30 minutes, 1 hour, 2 hours and overnight. Following fixation, they were treated with an enzyme mixture containing $4 \%$ cellulase and $2 \%$ pectolyase $\mathrm{Y}-23$ at $37^{\circ} \mathrm{C}$ for 1 hour. Other details were same as the first experiment described above.

\section{RESULTS AND DISCUSSION}

\section{Effect of enzyme treatment}

A total of 108 slides was prepared for testing enzyme treatments. Two treatments of $4 \%$ cellulase and $2 \%$ pectolyase Y-23 for one hour and two hours gave the highest scoring with clearly stained and well separated chromosomes (Table 1). Treatment of $4 \%$ cellulase and $1 \%$ pectolyase Y-23 for one hour, and treatment of $4 \%$ cellulase and $2 \%$ pectolyase Y-23 for 30 minutes also provided fairly good results though poorer quality for photomicrography. Pectolyase Y-23 treatment provided best results and it was suitable for sorghum plants. However, increasing pectolyase concentration in enzyme mixture made occasional cell fusions. Optimum duration of treatment for treating was from one to two hours. Long duration of treatment often caused inferior results. For example, 
Table 1. Effects of enzyme treatment on slide preparations.

\begin{tabular}{lc}
\hline \multicolumn{1}{c}{ Treatment* } & Means of Scoring \\
\hline Enzyme (1), treated for 30 min. & $55.0 \mathrm{ab} * *$ \\
Enzyme (1), treated for 1 hour & $77.3 \mathrm{a}$ \\
Enzyme (1), treated for 2 hours & $22.0 \mathrm{~b}$ \\
Enzyme (2), treated for 30 min. & $77.3 \mathrm{a}$ \\
Enzyme (2), treated for 1 hour & $88.7 \mathrm{a}$ \\
Enzyme (2), treated for 2 hours & $88.7 \mathrm{a}$ \\
Enzyme (3), treated for 30 min. & $66.3 \mathrm{ab}$ \\
Enzyme (3), treated for 1 hour & $66.3 \mathrm{ab}$ \\
Enzyme (3), treated for 2 hours & $44.0 \mathrm{ab}$ \\
\hline$*$ Enzyme (1) consisted of 4\% cellulase and 1\% pectolyse Y-23; enzyme (2) consisted \\
of 4\% cellulase and 2\% pectolyase Y-23; enzyme (3) consisted of 5\% cellulase and \\
$3 \%$ pectolyase Y-23.
\end{tabular}

overnight treatment was not successful for all three kinds of enzyme mixture studied.

In a sub-experiment, significant effects of changing duration in a fixative were not detected. However, treatments of one or two hours had a tendency of better results. Overnight treatment gave unsatisfactory results.

\section{Cytology}

Result from this study showed that chromosome number in all four cultivars was $2 n=$ 20. This confirmed the previous reports (Gu et al., 1984; Sangduen et al., 1984; Wu, 1993). Diploid cells $(2 n=20)$ were predominant in the root tips in all four cultivars and its frequency ranged from 95.6 to $97.2 \%$. A few tetraploid cells and haploid cells were observed with the frequencies ranged from 0.0 to $0.8 \%$ and 2.4 to $4.4 \%$, respectively, where generally mitotic cells had 20 chromosomes (Table 2). PP290 had higher percentage of haploid cells as compared to other three cultivars. Tetraploid cell was not found in Xin white and PP290. This finding agreed with results of Tang et al. (1987) that a few haploid and tetraploid cells were observed in $S$. bicolor. The phenomena of chromosomes associated in various configurations at metaphase were noticed. In some cases chromosome were associated into 2 groups of six and 2 groups of four chromosomes (Fig. 1. D). End-to-end association was also observed in TX403 (Fig. 1. E).

Table 2. Frequencies of different cytotypes in four sorghum cultivars.

\begin{tabular}{lrrrr}
\hline \multicolumn{1}{c}{ Cultivar } & Haploid cell & Diploid cell ${ }^{*}$ & Tetraploid cell & $\begin{array}{c}\text { Total cells } \\
\text { observed }\end{array}$ \\
\hline Xin White & $3(2.8)$ & $105(97.2)$ & 0 & 108 \\
PP290 & $6(4.4)$ & $128(95.6)$ & 0 & 134 \\
C8 & $4(2.7)$ & $144(96.6)$ & $1(0.6)$ & 149 \\
TX403 & $3(2.4)$ & $120(96.8)$ & $1(0.8)$ & 124 \\
\hline
\end{tabular}

* Diploid cell had $2 n=20$ chromosomes. Values in parentheses are percentage of particular cytotype observed. 

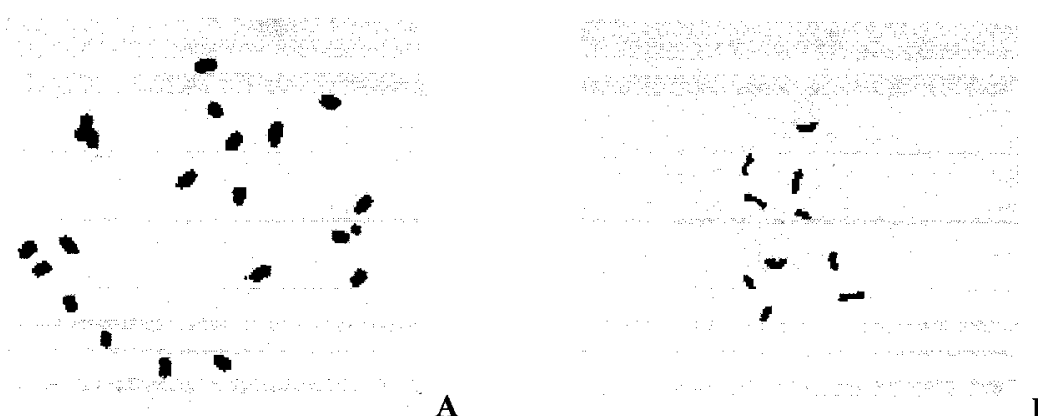

A
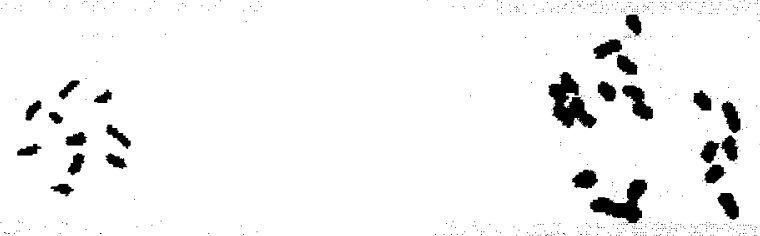

C

D

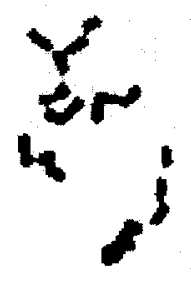

$\mathbf{E}$
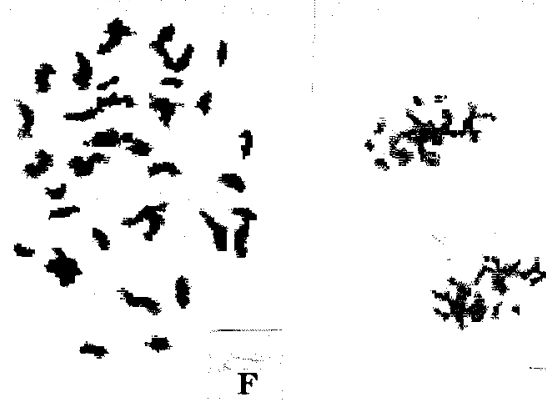

G

Fig. 1. Photomicrographs of chromosome in sorghum root tip cells. A _ a metaphase cell from TX403 with $2 n=20$. B a haploid cell with 10 chromosomes in TX403. C a haploid cell $2 n=10$ with one smallest chromosome in PP290. D_ a metaphase cell from TX403 showing chromosome associated into 2 groups of six and 2 groups of 4 chromosomes. $\mathrm{E}$ end-to-end association and grouped of chromosomes in TX403. F a tetraploid cell with chromosome around 40 in C8 cultivar. G_anaphase I in Xin White.

The variability of chromosome configuration was reported in previous studies (Tang et al., 1987).

There was a variation in length of chromosomes in four cultivars studied. Some 
Table 3. Chromosome size in four sorghum cultivars.

\begin{tabular}{lcc}
\hline \multirow{2}{*}{ Cultivar } & \multicolumn{2}{c}{ The range of chromosome size in $\mu \mathrm{m}$} \\
\cline { 2 - 3 } & Smallest* & Majority \\
\hline Xin White & $1.25-2.00$ & $2.50-3.75$ \\
PP290 & $1.25-2.00$ & $2.50-5.00$ \\
C8 & $1.50-2.00$ & $3.00-5.50$ \\
TX403 & $1.25-2.00$ & $2.50-4.50$ \\
\hline
\end{tabular}

* The length of smallest and majority chromosomes was estimated from 3 to 4 cells for each cultivar.

smallest chromosomes often appeared in the root tip cells. The length of smallest chromosomes varied from 1.25 to $2.0 \mu \mathrm{m}$ while the majority of chromosome was from 2.5 to $5.5 \mu \mathrm{m}$ (Table 3). It seems that the length of chromosomes of PP290 and C8 was longer than those of other two cultivars. The length of chromosomes varied between 2.5 to $3.75 \mu \mathrm{m}$ for Xin white, 2.5 to $4.5 \mu \mathrm{m}$ for TX403, while it ranged from 2.5 to $5.0 \mu \mathrm{m}$ and 3.0 to $5.5 \mu \mathrm{m}$ for PP290 and C8, respectively. This measurement was an agreement with observations from Gu et al. (1984) with chromosome size ranging between $2.27-5.60 \mu \mathrm{m}$ in $S$. bicolor, except the smallest chromosomes.

For conclusion, root tips treated with pectolyase Y-23 provided best results. Treatments of root tips treated with enzyme mixture containing $4 \%$ cellulase and $2 \%$ pectolyase $\mathrm{Y}-23$ at $37^{\circ} \mathrm{C}$ for one or two hours gave satisfactory slide preparations, in which chromosomes were stained darkly and clearly, could be easily counted and had good quality for photomicrography. There was a variation in chromosome size but it mostly ranged from 2.5 to $5.5 \mu \mathrm{m}$ in all four cultivars of $S$. bicolor. The phenomena of chromosome association were also observed. From this study, using mixed enzyme solution of $4 \%$ cellulase and $2 \%$ pectolyase Y-23 was most suitable to sorghum plants. Efforts for getting good slide preparations and cytological observations in sorghum root tip cells could be achieved by applying this method.

\section{ACKNOWLEDGEMENTS}

The authors wish to thank Prof. T. P. Wu, Department of Botany, National Taiwan University, Taipei, Taiwan, Repulic of China for the critical reading of the manuscript.

\section{REFERENCES}

Brock, R. D. and A. J. Pryor 1996 An unstable minichromosome generates variegated oil yellow maize seedlings. Chromosoma, 104: 575-584

Bukenya, Z. R. and J. F. Carasco 1995 Crossability and cytological studies in Solanum macrocarpon and Solanurn linnaeanum (Solanaceae). Euphytica, 86: 5-13

Gonzalez, A. I, M. I. Pelaez and M. L. Ruiz 1996 Cytogenetic variation in somatic tissue cultures and regenerated plants of barley (Hordeum vulgare L.). Euphytica, 91 : 37-43

Gu, M.H., H. T. Ma and G. H. Liang 1984 Karyotype and analysis of seven species in the genus Sorghum. J. Hered., 75: $196-202$

Hyuga, Y. 1990 Chromosome observation. In "Guide to Experiment in Agricultural Sciences", ed. by Department of Agronomy, Faculty of Agriculture, Tohoku University. Soft science publications, Tokyo, 
pp. $31-33$

Kurata, N. and T. Omura 1978 Karyotype analysis in rice. I. A new method for identifying all chromosome pairs. Japan. J. Genetics, 53: 251-255

Murata, M., N. Nakata and Y. Yasumuro 1992 Origin and molecular structure of a midget chromosome in a common wheat carrying rye cytoplasm. Chromosoma, 102: 27-31

Ohta, S. 1991 Cytogenetical study on the speciation of Bupleurum falcatum L. Journal of Science of the Hiroshima University, Ser. D, Div. 2 (Botany), 23: 273-348

Sangduen, N. and W.W. Hanna 1984 Chromosome and fertility studies on reciprocal crosses between two species of autotetraploid sorghum. J. Hered., 75: 293-296

Tang, H, and G. H. Liang 1987 An improved tcchnique for cytological observations and occurrence of polysomaticism in sorghum root tips. The Joumal of Heredity, 78:51-53

Wu, T. P. 1993 Cytological and morphological relationships between Sorghum laxiflorum and S. bicolor. J. Hered., 84: 184-489 